\title{
Tissue injury and inflammation
}

\author{
Basileios Kokkas
}

From $1^{\text {st }}$ International Congress on Neurobiology and Clinical Psychopharmacology and European

Psychiatric Association Conference on Treatment Guidance

Thessaloniki, Greece. 19-22 November 2009

Inflammation is a very complicated phenomenon and consist a part of the immune response which is divided to a natural phase followed by an adaptive one. Tissue injury is followed by a cascade of events leading to the inflammatory response which is divided in three phases. The first phase of inflammation is manifested by the activation of the local tissue macrophagues which exert their phagocytic action and the mast cells which liberate cytokines and vasoactive substances. Cytokines are divided in proinflammatory, chemokines and immunoregulatory ones. Proinflammatory cytokines trigger the second phase of inflammation while chemokines create a chemotactic current. Immunoregulatory cytokines prepare the adaptive phase of the immune response. A certain number of vasoactive substances mediate an initial local vasoconstriction aiming to restrict the cause of tissue injury. This vasoconstriction is followed by a broader local vasodilatation and an increased permeability of the vascular wall. These last events permit to the inflammatory cells and macromolecules to reach the site of tissue injury. Many vasoactive substances like istamine, bradykinine, prospaglandins, leukotrienes and nitric oxide participate in these actions. During the second phase of inflammation, blood cells following the chemotactic current move to the site of injury and start their phagocytic activity. The third phase of inflammation is connected with the tissue restoration.

Published: 22 April 2010

doi:10.1186/1744-859X-9-S1-S1

Cite this article as: Kokkas: Tissue injury and inflammation. Annals of General Psychiatry 2010 9(Suppl 1):S1.

1st Department of Pharmacology, School of Medicine, Aristotle University of Thessaloniki, Greece

Submit your next manuscript to BioMed Central and take full advantage of:

- Convenient online submission

- Thorough peer review

- No space constraints or color figure charges

- Immediate publication on acceptance

- Inclusion in PubMed, CAS, Scopus and Google Scholar

- Research which is freely available for redistribution

Submit your manuscript at www.biomedcentral.com/submit
() Biomed Central 